Nigerian Journal of Environmental Sciences and Technology (NIJEST)

www.nijest.com

ISSN (Print): 2616-051X ｜ＩSSN (electronic): 2616-0501

Vol 2, No. 2 October 2018, pp 233 - 242

\title{
Tenants' Willingness to Pay for Green Features in Office Properties
}

\author{
Oyewole M. O. ${ }^{1, *}$ and Komolafe M. O. ${ }^{2}$ \\ ${ }^{1}$ Department of Estate Management, Obafemi Awolowo University, Ile Ife, Nigeria \\ ${ }^{2}$ Department of Estate Management, University of Benin, Benin City, Edo State, Nigeria \\ Corresponding Author: *wolesike@yahoo.com
}

\begin{abstract}
The study investigates tenants' willingness to pay for green features in office properties in Lagos, Nigeria. This is with a view to determining the inclinations of users to green buildings. Data for the study were collected through the use of structured questionnaire administered using purposive sampling. Tenants' Willingness To Pay Index (TWTPI) was used to measure the tenants' willingness to pay for green building features. The features considered were 'Water, Rain Water and Sewage', Site Selection, Site Design and Land Scape Ecology', 'Building Ecology, 'Waste and Recycling', 'Indoor Air Climate', Material use and Conservation', and Owner and Occupant Education'. The willingness of tenants to pay for features such as 'Energy Conservation', 'Water, Rain Water and Sewage' and 'Site Selection, Site Design and Land Scape Ecology' ranked first, second and third with TWTPI of 3.12, 2.72 and 2.71respectively. This finding shows that the majority of the features had a TWTPI of less than 3(out of 6) indicating that the level of willingness of tenants to pay for the majority of green features was below average. The paper advocates for relevant agencies to embark on aggressive awareness campaign which emphasizes the direct benefits of green building.
\end{abstract}

Keywords: Environment, Green features, Office properties, Sustainability, Willingness-ToPay

\subsection{Introduction}

The turn of the century has witnessed an increasing concern for sustainability in real estate industry, with major stakeholders: investors, developers, and users trying to embrace sustainability agenda (Royal Institute of Chartered Surveyors, 2010). While the concern may be partly attributed to global focus and advocacy for sustainable investment, the additional benefits and costs that may be incurred by investing or occupying sustainable or green building have combined to produce a formidable force for driving sustainability agenda in the real estate industry. While it will take extra costs to integrate green features in building construction, the benefits of incorporating the features include reduction or elimination of negative impacts on the environment, energy efficiency, water efficiency, improved health and wellbeing of occupiers, higher rental rate, and lower vacancy rate (World Green Building Council, 2013; McGraw Hill Construction, 2014).

Investment in green buildings has been encouraged through government legislation in most developed economies. However, evidence in literature suggests that the response by the private sector has been slow owing to lack of evidential proof of economic viability of green building investment (Myers et al., 2007). Meanwhile, the willingness of tenants (space consumers) to pay and the extent to which they are willing to pay for green features are major concerns of the developers and investors particularly in emerging economies at present. Whether the tenants are willing to pay additional costs for green features or not has been a main subject of sustainable investment literature of recent (see for instance, Banfi et al., 2008; Wiencke, 2013; Simons et al., 2014). Such information is demonstrably 
valuable in providing an improved understanding for the potential and viability of green building investment.

Sustainability in property investment, particularly the willingness to pay for green features has to date been dominated by developed economies such as the United States of America, the United Kingdom and Australia. Evidence from literature shows that majority of the studies were carried out in developed economies where strong advocacy for sustainable development exist. While a few studies (e.g. Oladokun et al., 2010; Nwokoro and Onukwube, 2011; Oyewole et al., 2012; Komolafe et al., 2016; Oyewole and Komolafe, 2018), have been carried out on sustainable or green building in developing and emerging countries like Nigeria, studies on tenants' willingness to pay for green features are lacking. Meanwhile, sustainability as reasoned by Krosinsky and Robins (2008) has more urgent priorities among world's growing countries. It is imperative for Nigeria and other emerging economies of the world to adopt sustainable property investment owing to the fact that the countries are confronted by unprecedented population growth, environmental degradation, and poor living and working environment. This study therefore bridges the observed omission in literature by investigating the tenants' willingness to pay for green features in office properties in Lagos, Nigeria.

Studies relating to willingness to pay for green features abound. Grosskopf (2003) examined the extent to which "capital construction costs and life-cycle return on investment influenced tenants' willingness to pay for green building alternatives" in Florida. The author complemented the performance of more than 100 high efficiency buildings simulated in the three major climatic regions to a consumer willingness-to-pay survey of more than 400 new home buyers. The result showed that willingness to pay for social and ecological benefits excluding economic returns vary widely from $33.8 \%$ to $61.1 \%$. It was also revealed that willingness to pay decisions of respondents vary mainly by age and income. Yau (2012) examined residents' willingness to pay and preferences for green housing features in Hong Kong. The author employed structured questionnaire survey and found that apart from moral or altruistic reasons, residents' willingness to pay was largely influenced by monetary incentives. The study also revealed that residents were more willing to pay for features directly linked with reduction in utilities bill. However, it should be noted that the investigation was carried out on residential property investments and not office properties.

Kotchen et al. (2013) estimated the willingness to pay in support of a national climate-change policy that was akin to the costs of actual legislative efforts in the U.S congress. The authors carried a survey of 2034 American adults and found that households were willing to pay between 79 and 89 dollars per year in support of reducing domestic greenhouse gas emission. Apart from the fact that the study was carried out in a developed economy, the study did not specifically targeted office property users.

Wiencke (2013) investigated the firms' willingness to pay for green features in Switzerland. The author employed data from corporate real estate and sustainability survey and found that Swiss corporations were willing to pay a premium price of $3.0 \%$ for leasing, $4.75 \%$ for purchasing and $5.0 \%$ for retrofitting. The result also showed that firms from building and financial service industries as well as public corporations and authorities indicated the highest willingness to pay.

Simons et al. (2014) examined office tenants' willingness to pay for green features in the United States of America. The study considered eighteen (18) green building features and discovered that tenants were willing to pay a premium of $9.3 \%$ on office buildings. The result also indicated that the tenants' level of willingness to pay ranked highest for improved indoor air quality and access to natural light. Apart from the fact that the study was carried out in a developed economy, the study covered a fewer number of green features to the exclusion of other features such as "availability of tenants' sub-metering (on energy, water etc.) and "availability of waste reduction work plan" among others.

Park et al. (2013) investigated consumers' willingness to pay for certain green features of residential buildings in Seoul. The authors employed conjoint analysis and ranking method found that the marginal willingness to pay for $1 \%$ reduction of carbon dioxide emission was estimated about 377 USD, two times higher than that for reduction of volatile organic compound VOC emissions and almost the same as that for the reduction of energy bills. The result also indicated that energy bill was most preferred while IT facilities were the least preferred by the residents. Although the study was 
carried out in an emerging economy, the study did not consider office property users. ZalejskaJonsson (2014) measured the stated and rational willingness to pay for green apartment in Sweden. The study considered the responses of residents of green and conventional multi-family buildings to investigate the existence of willingness to pay and to test the difference in the perception of those living in green and those living in conventional building. The result showed that respondents were willing to pay for green building but not as willing to pay for buildings with environmental certificate.

In the Nigerian context, Oladokun et al. (2010), explored the perception of property developers and tenants on the prospects and difficulties associated with the adoption of green buildings. The analysis revealed that the respondents were not willing to adopt green building but were of the opinion that green building would be desirable in the future. Oyewole et al. (2012) investigated the degree of involvement of Nigerian real estate investors in sustainable (green) property investment practice. The authors carried out a survey of eighteen property companies in Lagos and found that insignificant attention was given to social and environmental issues in their investment activities. Although, the study focused in the Lagos property market, the perception of the tenants who are the occupiers of the investment properties was not examined.

Komolafe and Oyewole (2015) examined the estate surveyors and valuers' perception of users' preference for green features in office properties in Lagos. The study employed relative preference index and revealed that users preferred most of the green features to conventional building features. However, the study only considered the opinions of real estate practitioners and not the views of the users who were the object of the study.

In an attempt to bridge the gap in the previous study (Komolafe and Oyewole, 2015), Oyewole and Komolafe (2018) examined users' preference of office properties. The study focused on the users of office buildings in Lagos and found that users' preference for green features in office properties was above average. The analysis also revealed that features relating to 'building ecology, waste and recycling' were the most preferred, while those relating to 'owner and occupant education' were the least preferred. Though, the study focused on the preference of the users, the extent of their willingness to pay for the respective feature was not investigated.

Olaleye et al. (2015) examined the perception of industrial and commercial property users on green buildings. The study employed mean and relative importance index, and found that 'reduced resource utilization' and 'improved quality of work life' were the two top tanked advantages that could prompt industrial and commercial property users to pay for green features.

This paper is germane for two reasons. First, the study covers more features of green buildings unlike the previous studies (Park et al., 2013; Simons et al., 2014) that focused on some specific elements. Second, existing studies on sustainability, especially in Nigeria literature (Oyewole et al., 2012; Olaleye et al., 2015; Oyewole and Komolafe, 2018) focused less on tenants' willingness to pay for green features. Office property tenants are viable target for investment in green building and are very important to sustainable development agenda particularly in the area of built environment.

\subsection{Methodology}

In order to investigate the tenants' willingness to pay for green features in office properties, the study employed data collected through questionnaire from the tenants of office properties in the management portfolio of estate surveying and valuation firms in Lagos in Lagos, Nigeria. In total 88 (representing 20\% of 440 estate surveying and valuation firms in the study area) were sampled for ease of coverage. In the administration of questionnaire, 2 office properties were sampled purposively from the portfolio of each sampled firms. The selection was purposively done to cover different location, age of the property, use intensity and tenant type. In each selected property, two tenants were selected purposively from each sampled property. Thus, a total of 352 tenants in 176 properties were selected for sampling.

In earlier works by the authors (Komolafe and Oyewole, 2015; Komolafe et al., 2016), building attributes with energy conservation; indoor air climate; material use and conservation; water, waste 
and waste recycling; site selection, site design and landscape ecology and owner and occupant education features were identified as green features. These features constitute variables used in this study.

The respondents were asked about their socio-economic characteristics; their perception as to whether they were willing to pay; their level of willingness and the amount they were willing to pay for the respective green features. The tenants were further asked to rate each of the features using Likert's scale of not at all willing, willing to pay a cost premium 1-5\%, willing to pay a cost premium of 6$10 \%$, willing to pay a cost premium 11-20\%, willing to pay a cost premium $21-30 \%$ and willing to pay a cost premium of above $30 \%$.During analysis, these ratings were assigned weight values of 1, 2, 3, 4, 5 and 6 respectively. The tenants' willingness to pay index (TWTPI) for each of the variables was arrived at by dividing the summation of weight value (Total weight value - TWV) by the total number of respondents. The TWV is the addition of product of the number of responses to each of the variables and the weight values attached to each rating (see Afon, 2007; Oyewole, 2010). The TWTPIs thus ranged between the values of 6 and 1. This is expressed mathematically as:

$T W V=\sum_{\substack{i=1 \\ \text { where: }}}^{6} P_{i} V_{i}$

$T W V$ is the total weight value,

$P_{i}$ is the number of respondents rating an attribute $i$, and

$V_{i}$ is the weight assigned to each attribute $i$.

The TWTPI to each attribute is arrived by dividing TWV by the summation of the respondents to each of the six ratings of an attribute. This is expressed mathematically as:

$T W T P I=\frac{T W V}{\sum_{i=1}^{6} P_{i}}$

where:

TWTPI is the relative willingness index and $\mathrm{P}_{\mathrm{i}}$ is as defined previously.

The closer the TWTPI of an attribute is to six, the higher the assumed relative willingness. The mean of the TWTPI distribution was computed. The deviation about the mean of each variable was also computed to measure the scatter in the data relative the mean

\subsection{Results and Discussion}

In presenting the results of the study, the paper first examined the characteristics of tenants and subsequently on their level of willingness to pay for green features.

\subsection{Characteristics of tenants}

The characteristics of office properties' tenants are as shown in Table 1 below. The result shows that majority of responding tenants are males $(59.8 \%)$, whose ages range between 31 and 40 years $(35.3 \%)$ with first (HND/B.Sc) degree $(41.1 \%)$. The result also reveals that majority of the respondents were senor staff (29.0) with between 6 and 10 years of experience.

The analysis of the occupation of the respondents indicates that they were engaged in various activities such as professional services, financial services, recruitment and training, business services and manufacturing. The result further reveals that majority of the respondents (44.8) were engaged in business services, while $27.4 \%, 12.9 \%, 7.5 \%$, and $7.5 \%$ were engaged in professional services, financial services, recruitment and training and manufacturing activities respectively. 
Table 1: General characteristics of tenants

\begin{tabular}{|c|c|c|}
\hline Characteristics & Frequency & Percentage \\
\hline \multicolumn{3}{|l|}{ Gender } \\
\hline Male & 144 & 59.8 \\
\hline Female & 97 & 40.2 \\
\hline Total & 241 & 100.0 \\
\hline \multicolumn{3}{|l|}{ Age } \\
\hline $20-25$ & 30 & 12.4 \\
\hline $26-30$ & 67 & 27.8 \\
\hline $31-40$ & 85 & 35.3 \\
\hline $41-50$ & 33 & 13.7 \\
\hline 51 and above & 8 & 3.3 \\
\hline No response & 18 & 7.5 \\
\hline Total & 241 & 100.0 \\
\hline \multicolumn{3}{|c|}{ Highest Educational Qualification } \\
\hline O' level certificate & 19 & 7.9 \\
\hline ND & 90 & 37.3 \\
\hline $\mathrm{HND} / \mathrm{BSc}$ & 99 & 41.1 \\
\hline Masters & 18 & 7.5 \\
\hline $\mathrm{PhD}$ & 0 & 0.0 \\
\hline No response & 15 & 6.2 \\
\hline Total & 241 & 100.0 \\
\hline \multicolumn{3}{|l|}{ Occupation } \\
\hline Professional services & 66 & 27.4 \\
\hline Financial services & 31 & 12.9 \\
\hline Recruitment and training & 18 & 7.5 \\
\hline Business services & 108 & 44.8 \\
\hline Manufacturing & 18 & 7.5 \\
\hline Total & 241 & 100.0 \\
\hline \multicolumn{3}{|l|}{ Official Designation } \\
\hline Business Owner & 28 & 11.6 \\
\hline General Manager/Assistant & 31 & 12.9 \\
\hline Sectional Head/assistant & 46 & 19.1 \\
\hline Senior Staff & 70 & 29.0 \\
\hline Junior Staff & 48 & 19.9 \\
\hline No response & 18 & 7.5 \\
\hline Total & 241 & 100.0 \\
\hline
\end{tabular}

\subsection{Tenants' willingness to pay for green features}

This section examines the willingness of users to pay for green building features. The willingness of the responding tenants to pay is examined across the categories of green features examined earlier. The result on the cost premium willing to be paid on each category by the users is as presented in Table 2. The tenants' level of willingness to pay for green features was assessed. This is through tenants' willingness to pay index (TWTPI), computed for each of the green features.

The result in Table 2 showed that majority of the features had a TWTPI of less than 3 (out of 6). This indicates that the level of willingness of tenants to pay for majority of green features in the study area was below average. The study also revealed that the features that ranked first and second in terms of TWTPI are 'energy conservation' with TWTPI of 3.12 and 'water, rain water and sewage' with TWTPI of 2.72 respectively. This finding is in line with Oyewole and Komolafe (2018) that property users in the study area were confronted with severe difficulty in the area of power and water supply. Office property users in the study area depend mainly on public power supply which is erratic in supply necessitating the provision of additional source of power. The tenants might also be willing to pay for water saving facilities to ration the use of water which is considered essential for their daily usage.

The analysis on green features relating to energy conservation shows that 'Availability of contingency plans for power supply' attracts the highest TWTPI of 4.87 while 'Growing of natural vegetation in the surrounding environment attracts the lowest TWTPI of 1.97. The average TWTPI for this group of features is 3.12. Other features with TWTPI higher than average are 'Installation of low-basic energy lighting' (4.01),'Design for low energy intensive in-house and public transportation' (3.45), 'Energy recovery ventilation systems' (3.35) and 'Use of natural cooling systems' (3.15). Each of the features 
in this category thus had a positive deviation about the mean. The implication of this is that the degree of willingness to pay for these features is higher than average level of willingness the tenants had to pay for green features relating to energy conservation. Further analysis indicates that six of these features had the negative deviation about the mean of TWTPI. These features are 'Use of natural cooling systems', 'Use of solar cells, winds or photovoltaic means for power supply', 'Use of natural lighting systems', Maximizing the contribution of passive solar energy without reducing the comfort in periods with high solar exposure', 'Energy optimized windows', Design for energy efficient deconstruction and recycling' and Growth of natural vegetation in the surrounding environment'. The deviations about the mean of TWTPI for features relating to energy conservation for the above listed features are $-0.11,-0.28,-0.37,-0.38,-0.94$ and -1.15 respectively.

The result of the study on features relating to 'Water, rain water and sewage' reveals that" Water saving toilet and bath facilities' shows that the highest WTPI is 4.55 while the least is 1.94 . The feature with the highest WTPI was 'Water saving toilet and bath facilities' while design for dual plumbing had the lowest. The average TWTPI for features in this category is 2.72 . Other feature with TWTPI higher than the average for this group of features is 'Water efficient plumbing features' with TWTPI of 3.84. Features such as 'Collection of rain water for Utilization to lessen pressure on potable water', 'Waste water reutilization', Pressure reducing mechanisms on the plumbing features' and 'design for dual plumbing features' had a negative deviations about the mean of group of features in this category. A glance at the result also shows that the aforementioned features with negative deviations also attracted TWTPI of less than average (less than 3 out of maximum 6) implying that the level of tenants' willingness to pay for the features was low.

Regarding features relating to 'Site selection, site design and landscape ecology', 'Access to public transport within reasonable time' attracted the highest TWTPI (4.25), followed by 'Good lighting controls' (3.55), while 'A green common area is included in the main plot attracted the least TWTPI (1.98). The average TWTPI for this category of green features is 2.71 . Other features with TWTPI higher than the average of all features in the group are 'Space sufficiency' (3.50) and 'Design is flexible to allow for easy conversion' (3.45). The finding as revealed in the table shows that the willingness of tenants to pay for most (eight) of features in this category of green features is below average (3 out of 6$)$.

Among features relating building ecology, waste and recycling, 'Control of site pollution' attracted the highest TWTPI (4.15) among features as most tenants were willing to invest in properties with features that would enable them to safeguard pollution with a view to ensure that their offices are located in an area 'free from contamination' which ranked next with TWTPI of 4.12. The average TWTPI for the green features relating to 'building ecology, waste and recycling' was 2.64. Other features with TWTPI higher than the average included 'Right channelization of water drain' (3.95) and 'Availability of storm water management measures' (2.95). Features with TWTPI lower than the average of this category of features included 'Noise from installations is kept moderate and under control' (2.45), 'Waste water is treated from sinks and showers' (2.12),' Means of waste diversion from living areas where it could be toxic' (2.08),' Facilities for Storing and Handling Recyclable Materials' (2.01),' Measures to ensure that food or food waste is well contained' (1.95),' Collection points for sorting wastes into paper, glass, metal and plastic for treatment' (1.90) and 'Construction, renovation and demolition waste management policy' (1.36). Each of the features in this category thus had a negative deviation about the mean of TWTPI of features relating to 'Building ecology, waste and recycling'. The implication of this is that the degree of willingness of tenants to pay for these features is lower than the average of their willingness to pay for green features relating to building ecology, waste and recycling.

The result of analysis on green features relating 'Indoor air climate' shows that TWTPI of most of the features was below average (3.00) and also attracted negative deviations about the mean of TWTPI (2.38) of the group. Location of air intakes far from sources of pollution' attracted the highest TWTPI (4.39) followed by 'Building design to utilize natural and cross ventilation' (3.43). Other features such as 'In-door materials that are less air-toxic', 'Mechanical ventilation of enclosed parking areas', 'Building effective local exhaust into heavy equipment rooms', and 'A building design which avoids the need for air condition/cooling systems' (1.15) had TWTPI lower than the average and negative 
deviations of $-0.37,-0.50,-0.95$ and -1.23 respectively. The results show that features not directly associated with occupants comfort had TWTPI lower than the average suggesting that tenants had low priority for the features.

Among features relating to 'Materials use and Conservation', 'Availability of equipment on-site to deal with environmental emergencies' ranked highest in terms of TWTPI (3.51) followed by 'use of durable materials' (TWTPI $=3.15$ ) while 'Avoidance of Foam materials using CFC and HCFC' ranked least with a TWTPI of 1.44. The average TWTPI for this category of green features is 2.21 . Further analysis indicates that five of these features have negative deviations about TWTPI of green features relating to 'Materials use and Conservation'. These features are 'Use of materials that protect against the local weather conditions', 'Water installations, cable works and related installations without toxic PVC', 'Use of recyclable/recycled materials in construction', 'Use of natural and local materials in construction' and 'Avoidance of Foam materials using Chlorofluorocarbon (CFC) and Hydrochlorofluorocarbon (HCFC)'. The implication of this is that the level of willingness of tenants to pay for these features is lesser than the average level of willingness to pay for 'Materials use and Conservation'. The deviations about the TWTPI for that category of features are $-0.06,-0.15,-0.56,-$ 0.70 and -0.77 . The level of willingness to pay expressed by respondents on 'Availability of equipments on-site to deal with environmental emergencies' is not unexpected as the tenants who were involved in various business activities, would always be willing to make provision for the protection of their lives and properties.

The aggregate (mean) of tenants' level of willingness to pay for features relating to 'Owner and Occupant Education' is 1.84. Further analysis indicates that two features have positive deviation about the mean of TWTPI of features relating to 'Owner and Occupant Education'. These features are 'Availability of regular procedure for checking and fixing leaks' (2.41), 'Availability of checklist of items connected to Indoor Air Quality that must be discussed with architects, engineers, contractors, and other professionals prior to renovations and repairs' (1.97), 'Availability of regular maintenance schedule' (1.87) and 'Availability of Emergency response Manuals' (1.85). The result reveals that all features in this category of green features attracted TWTPIs that are lesser than the average (3.0 out of 6.0). The implication of this is that the level of willingness of the respondents to pay for these features was low.

In summary, the finding of this study showed that tenants were more favourably disposed and willing to pay for green features that confer comforts to occupants rather than those that confer benefits to the environment. This finding is not unexpected and in line with the outcomes of the earlier studies (Komolafe and Oyewole, 2015; Oyewole and Komolafe, 2018) on the preference of users for green features. The implication of this is that the tenants were more inclined to pay for features that confer occupants comforts such as 'Availability of contingency plans for power failure', 'Water saving toilet and baths facilities', 'Access to public transport within reasonable time', and 'Location of air intakes far from sources of pollution', it is recommended that tenants should be educated on the importance of features that are eco-friendly in order to enhance the sustainability of built environment.

Table 2: Tenants' willingness to pay for green features

\begin{tabular}{|l|l|l|l|}
\hline Green features & TWTPI & TWTPI - TWTPI & Ranking \\
\hline Energy Conservation & & & $\mathbf{1}$ \\
\hline $\begin{array}{l}\text { Availability of contingency plans for power failure (eg...power inverter, solar } \\
\text { products and kits..............) }\end{array}$ & 4.87 & 1.75 & 1 \\
\hline Installation of low-basic energy lighting & 4.01 & 0.89 & 2 \\
\hline Design for low energy intensive in-house and public transportation & 3.45 & 0.33 & 3 \\
\hline Energy recovery ventilation systems & 3.35 & 0.23 & 4 \\
\hline Use of natural cooling systems & 3.15 & 0.03 & 5 \\
\hline Use of solar cells, winds or photovoltaic means for power supply & 3.01 & -0.11 & 6 \\
\hline Use of natural lighting systems & 2.84 & -0.28 & 7 \\
\hline $\begin{array}{l}\text { Maximizing the contribution of passive solar energy without reducing the } \\
\text { comfort in periods with high solar exposure }\end{array}$ & 2.75 & -0.37 & 8 \\
\hline Energy optimized windows & & & \\
\hline Design for energy efficient deconstruction and recycling & 2.74 & -0.38 & 9 \\
\hline Growth of natural vegetation in the surrounding environment & 2.18 & -0.94 & 10 \\
\hline & 1.97 & -1.15 & 11 \\
\hline Water, Rainwater and Sewage & $\mathbf{3 . 1 2}$ & & \\
\hline
\end{tabular}




\begin{tabular}{|c|c|c|c|}
\hline Green features & TWTPI & TWTPI - TWTPI & Ranking \\
\hline Water saving toilet and baths facilities & 4.55 & 1.83 & 1 \\
\hline Water efficient plumbing features & 3.84 & 1.12 & 2 \\
\hline Collection of rain water for Utilization to lessen pressure on portable water & 2.03 & -0.69 & 3 \\
\hline Waste water reutilization & 2.01 & -0.71 & 4 \\
\hline Pressure reducing mechanisms on the plumbing features & 1.95 & -0.77 & 5 \\
\hline \multirow[t]{2}{*}{ Design for dual plumbing } & 1.94 & -0.78 & 6 \\
\hline & 2.72 & & 7 \\
\hline Site Selection, site design and land scape ecology & & & 3 \\
\hline Access to public transport within reasonable time & 4.25 & 1.54 & 1 \\
\hline Good lighting controls & 3.55 & 0.84 & 2 \\
\hline Space sufficiency & 3.50 & 0.79 & 3 \\
\hline Design is flexible to allow for easy conversion & 3.45 & 0.74 & 4 \\
\hline $\begin{array}{l}\text { Availability of controllable internal or external blinds and light fixtures that } \\
\text { prevent glare at Visual Display Terminals }\end{array}$ & 2.45 & -0.26 & 5 \\
\hline Shading of glazing (windows) is achieved when necessary & 2.43 & -0.28 & 6 \\
\hline Building design allows for non-destructive inspection & 2.42 & -0.29 & 7 \\
\hline Sufficient acoustic privacy & 2.30 & -0.41 & 8 \\
\hline $\begin{array}{l}\text { Ease, in open office areas, to engage in a conversation using a normal voice, } \\
\text { understand a phone conversation, and have a private conversation using } \\
\text { lowered voices }\end{array}$ & 2.16 & -0.55 & 9 \\
\hline The design is planned for an easy access to technical installations & 2.08 & -0.63 & 10 \\
\hline Sustainable landscaping & 2.00 & -0.71 & 11 \\
\hline \multirow[t]{2}{*}{ A green common area is included in each main plot of land } & 1.98 & -0.73 & 12 \\
\hline & 2.71 & & \\
\hline Building Ecology, Waste and Recycling & & & 4 \\
\hline Control of environmental Pollution & 4.15 & 1.51 & 1 \\
\hline Freedom of building area from contamination & 4.12 & 1.48 & 2 \\
\hline Right channelization of water drains & 3.95 & 1.31 & 3 \\
\hline Availability of storm water management measures & 2.95 & 0.31 & 4 \\
\hline Noise from installations is kept moderate and under control & 2.45 & -0.19 & 5 \\
\hline Waste water is treated from sinks and showers & 2.12 & -0.52 & 6 \\
\hline Means of waste diversion from living areas where it could be toxic & 2.08 & -0.56 & 7 \\
\hline Facilities for Storing and Handling Recyclable Materials & 2.01 & -0.63 & 8 \\
\hline Measures to ensure that food or food waste is well contained & 1.95 & -0.69 & 9 \\
\hline $\begin{array}{l}\text { Collection points for sorting wastes into paper, glass, metal and plastic for } \\
\text { treatment }\end{array}$ & 1.90 & -0.74 & 10 \\
\hline \multirow[t]{2}{*}{ Construction, renovation and demolition waste management policy } & 1.36 & -1.28 & 11 \\
\hline & 2.64 & & \\
\hline Indoor Air Climate & & & 5 \\
\hline Location of air intakes far from sources of pollution & 4.39 & 2.01 & 1 \\
\hline Building design to utilize natural and cross ventilation & 3.43 & 1.05 & 2 \\
\hline In-door materials that are less air-toxic & 2.01 & -0.37 & 3 \\
\hline Mechanical ventilation of enclosed parking areas & 1.88 & -0.50 & 4 \\
\hline Building effective local exhaust into heavy equipment rooms & 1.43 & -0.95 & 5 \\
\hline \multirow[t]{2}{*}{ A building design which avoids the need for air condition/cooling systems } & 1.15 & -1.23 & 6 \\
\hline & 2.38 & & \\
\hline Materials use and Conservation & & & 6 \\
\hline Availability of equipment on-site to deal with environmental emergencies & 3.51 & 1.3 & 1 \\
\hline Use of durable materials & 3.15 & 0.94 & 2 \\
\hline Use of materials that protect against the local weather conditions & 2.15 & -0.06 & 3 \\
\hline Water installations, cable works and related installations without toxic PVC & 2.06 & -0.15 & 4 \\
\hline Use of recyclable/recycled materials in construction & 1.65 & -0.56 & 5 \\
\hline Use of natural and local materials in construction & 1.51 & -0.70 & 6 \\
\hline \multirow[t]{2}{*}{ 4Avoidance of Foam materials using CFC and HCFC } & 1.44 & -0.77 & 7 \\
\hline & 2.21 & & \\
\hline Owner and Occupant Education & & & 7 \\
\hline Availability of regular procedure for checking and fixing leaks & 2.41 & 0.57 & 1 \\
\hline $\begin{array}{l}\text { Availability of checklist of items connected to Indoor Air Quality that must be } \\
\text { discussed with architects, engineers, contractors, and other professionals prior } \\
\text { to renovations and repairs }\end{array}$ & 1.97 & 0.13 & 2 \\
\hline Availability of regular maintenance schedule & 1.87 & 0.03 & 3 \\
\hline Availability of Emergency response Manuals & 1.85 & 0.01 & 4 \\
\hline $\begin{array}{l}\text { Availability of readily available operating manual covering standard control } \\
\text { settings and operating instructions for all services equipment that may affect } \\
\text { the energy consumption }\end{array}$ & 1.84 & 0.00 & 5 \\
\hline Availability of documented measures to control pollutants at source in areas & 1.82 & -0.02 & 6 \\
\hline
\end{tabular}




\begin{tabular}{|l|l|l|l|}
\hline Green features & TWTPI & TWTPI - TWTPI & Ranking \\
\hline $\begin{array}{l}\text { such as washrooms, kitchens, printing areas, chemical storage and general } \\
\text { storage areas }\end{array}$ & & & \\
\hline $\begin{array}{l}\text { Availability of communications to tenants on the environmental measures that } \\
\text { they can implement in the building }\end{array}$ & 1.80 & -0.04 & 7 \\
\hline Availability of Waste Reduction Work plan & 1.78 & -0.06 & 8 \\
\hline $\begin{array}{l}\text { Regular check of outdoor air intakes to ensure that the openings are protected } \\
\text { and free from obstruction. }\end{array}$ & 1.75 & -0.09 & 9 \\
\hline Availability of tenants' sub-metering (On energy, water, etc.) & 1.72 & -0.12 & 11 \\
\hline $\begin{array}{l}\text { Availability of carbon dioxide monitoring or sensors to maintain pre-set levels } \\
\text { of carbon dioxide. }\end{array}$ & 1.65 & -0.19 & 12 \\
\hline Availability of "Use \& Maintenance" manual & 1.62 & -0.22 & 12 \\
\hline & $\mathbf{1 . 8 4}$ & & \\
\hline
\end{tabular}

\subsection{Conclusion}

The study has provided information on the willingness of office property tenants to pay for various categories of green features. The aim is to evaluate the desire and readiness of tenants (office space users) to invest in green buildings. The degree of willingness of tenants to pay for various categories of green features was assessed through tenants' willingness to pay index (TWTPI). Moreover, the objective was to gain insight into the preparedness of office space users to embrace green buildings in the country.

The study also established that the willingness of tenants to pay for most of the groups of green features was low. Most of the features such as 'Water, Rainwater and Sewage' (2.72),' Site Selection, site design and land scape ecology' (2.71), 'Building Ecology, Waste and Recycling' (2.64), 'Indoor Air Climate' (2.38), 'Materials use and Conservation' (2.21) and 'Owner and Occupants' Education' (1.84) attracted TWTPI of less than the average (3.0 0ut of 6.0). Efforts should therefore be intensified to educate the tenants on the benefits of the features. It was also discovered that some green features such as 'Design for dual plumbing', Construction, renovation and demolition waste management policy', and 'Availability of use and Maintenance manual' ranked low in terms of tenants' willingness to pay. This might not be unconnected with what Oyewole and Komolafe (2018) ascribed as the level of importance of such features to management rather than tenants who might not have property management responsibilities. There is therefore the need to educate the users on the importance of such features to achieving full sustainability of built environment.

It is essential to point out some of the limitations of this study. First, features considered in this study were extracted from the various rating systems for green buildings in the developed economies and adapted as in Komolafe and Oyewole (2015) and Komolafe et al. (2016) owing to the absence of green building rating system in Nigeria. Second, some of the respondents (19.9\%) were junior staff who might not be in position to take decision on the payment of rent. The researcher resulted to obtain information from this group of people owing to the absence of their superiors. Third, because the purpose of the study was to examine tenants' willingness to pay for green features, the study did not investigate the factors responsible for their willingness.

\section{References}

Afon, A.O. (2007), Informal sector initiative in the primary sub-system of urban solid waste management in Lagos, Nigeria, Habitat International, 31(7), pp. 193-204.

Banfi,S., Farsi, M., Filipini, M. and Jakob, M. (2008), Willingness to pay for energy-saving measures in residential buildings, Energy Economics, 30(2), pp. 503-516.

Grosskopf, K.R. (2003), Investing in "green" building alternatives: US consumers' willingness-topay, The future of Sustainable Construction, pp. 1-8.

Komolafe, M.O and Oyewole, M.O. (2015). The Perception of Estate Surveyors and Valuers on Users' Preference for Green Buildings in Lagos, Nigeria, Proceedings of West African Built Environment Research (WABER) Conference, pp. 863-886, 10-12 August, 2015 Accra Ghana.

Komolafe, M.O., Oyewole, M.O. and Kolawole, J.T. (2016), Extent of incorporation of green features in office buildings in Lagos, Nigeria, Smart and Sustainable Built Environment, 5(3), pp. 232-260. 
Kotchen, M.J., Boyle, K.J. and Leiserowitz, A.A. (2013), Willingness-To- Pay and policy- instrument choice for climate-change policy in the United States,Energy Policy,55, pp. 617-625.

Krosinsky, C. and Robins, N. (2008), Sustainable Investing; The art of long-term Performance, Earthscan, London.

McGraw-Hill Construction,(2014) World Green Building Trends SmartMarket Report: Business Imperative and Market Demand Driving Green Building Growth. Retrieved from http://construction.com/about-us/press/world-green-building-trendssmartmarketreport.asp. .

Myers, G., Reed, R. and Robinson J. (2007), The relationship between sustainability and the value of office buildings, $13^{\text {th }}$ Annual Pacific Rim Real Estate Conference 21-24 January 2007, Curtin University of Technology, Perth. WA

Nwokoro, I. and Onukwube, H. (2011), Sustainable or Green Construction in Lagos, Nigeria: Principles, Attributes and Framework, Journal of Sustainable Development, 4(4), pp. 166-174.

Oladokun, T.T., Ogunba, O.A., Gbadegesin, J.T. (2010), Perceptual Analysis of the benefits and Implementation difficulties of Green Building in Lagos Metropolis, paper presented at the Nigerian International Research Conference on Suatainability in Built Environment, Colonbo, Sri Lanka, pp. 166-178.

Olaleye, A., Ayodele, T.O., and Komolafe, M.O. (2015), The relevance of Green Building Practice in an Emerging Markets: A Perceptual Analysis of Commercial and Industrial Building Users in Ibadan, Nigeria, Journal of Sustainable Real Estate, 7(1), pp. 41-49.

Oyewole, M.O. (2010), Housing development finance through cooperative societies, the case of Ogbomoso, Nigeria, International Journal of Housing Market and Analysis,3(3), pp. 245-255.

Oyewole, M.O., Araloyin, F.M. and Sani, K.S. (2012), Sustainable Property Investment Practice in Nigeria, Proceedings of International Conference on Construction and Real Estate Management (ICCREM), pp. 635-638, 01-02 October, Unversity of Kansas, Kansas City, USA.

Oyewole, M.O. and Komolafe, M.O. (2018), Users' preference for green features in office properties, Property Management, 36(4), pp. 374-388.

Park, M., Hargishima, A., Tanimoto, G. and Chun C. (2013), Willingness to pay for improvement for environmental performance of residential buildings. Building and Environment, 60, pp. 225-233.

Royal Institute of Chartered Surveyors (RICS) (2010), Is sustainability reflected in commercial property prices?: An analysis of evidence base Research Report, January 2010.

Simons, R., Lee, E. Robinson, S. and Kern, A. (2014), Demand for Green Buildings: Office Tenants' Willingness to Pay for Green Features, $2^{\text {nd }}$ Levin College Annual Research Conference, 21 August, 2014, CBRE Research College.

Wiencke, A. (2013), Willingness to Pay Green Buildings: Empirical Evidence from Switzerland, Journal of Sustainable Real Estate, 5(1), pp. 111-133.

World Green Building Council (2013), The Business Case for Green Building: A review of the costs and Benefits for Developers, Investors and Occupants, retrieved at www.wordgbc.org on 6/07/2018.

Yau, Y. (2012), Willingness to pay and preferences for green housing attributes in Hong Kong, Journal of Green Building: Spring, 7(2), pp. 137-152.

Zalejska-Jonsson, A. (2014), Stated WTP and Rational WTP: Willingness to pay for green apartment in Sweden, Sustainable Cities and Society, 13, pp. 46-56. 